ROCZNIKI TEOLOGICZNE

Tom LXVII, zeszyt 3 - 2020

DOI: https://doi.org/10.18290/rt.20673-3

\author{
KS. TADEUSZ ZADYKOWICZ
}

\title{
CHRZEST BRAMĄ CHRZEŚCIJAŃSKIEJ MORALNOŚCI. INSPIRACJE DOKUMENTU MIĘDZYNARODOWEJ KOMISJI TEOLOGICZNEJ WIARA I SAKRAMENTY
}

\author{
BAPTISM AS A GATE OF CHRISTIAN MORALITY. \\ INSPIRATIONS OF THE DOCUMENT \\ OF THE INTERNATIONAL THEOLOGICAL COMMISSION \\ THE RECIPROCITY BETWEEN FAITH AND SACRAMENTS \\ IN THE SACRAMENTAL ECONOMY
}

\begin{abstract}
Baptism is rightly called the gate - the gate to salvation, to eternal life, to the Church, the gate of life in the Spirit, the gate of hope, the gate to other sacraments. In a sense, it can also be called the gate of Christian morality. This name is implicitly suggested by the International Theological Commission document on the relationship between faith and the sacraments. Baptism is a gate, because by giving a participation in the Christ's death and resurrection, it constitutes the very subject of moral action and introduces man to active participation in the life of the Church and the world. This active participation is realized not only in worship, but also in moral life, which has its source in sacramental gifts. It is the realization in action of what baptism gives in the form of a gift. Christian moral life is therefore a consequence of passing through the baptism gate. This is its specificity.
\end{abstract}

Key words: baptism; sacraments; morality.

Chrześcijańskie życie moralne bywa niekiedy utożsamiane wyłącznie z posłuszeństwem przykazaniom oraz z poznaniem i zachowywaniem określonego

Ks. dr hab. TADEUSZ ZADYKOwICZ, prof. KUL - Katedra Teologii Moralnej Fundamentalnej i Ekumenicznej; Instytut Nauk Teologicznych; Katolicki Uniwersytet Lubelski Jana Pawła II; adres do korespondencji: Aleje Racławickie 14, 20-950 Lublin; e-mail: tadeuszz @ kul.pl; ORCID: https://orcid.org/0000-0002-1687-8286. 
zbioru przepisów ${ }^{1}$. Sprowadzenie tego życia jedynie do skrupulatnego wypełniania różnych nakazów i zakazów, a teologii moralnej do pouczania o tym, co wolno, a czego nie wolno czynić, prowadzi w skrajnych przypadkach do postrzegania moralności chrześcijańskiej jako synonimu zniewolenia. Nie negując rangi wysiłku człowieka, jakim jest niewątpliwie poddanie własnej wolności systemowi zasad i norm postępowania, trzeba ustawicznie zwracać uwagę na samą genezę moralności, której należy upatrywać w osobowym kontakcie człowieka z Bogiem jako źródłem powołania i obdarowania.

Dar Boga towarzyszy człowiekowi przez całe życie, jednak szczególny pod tym względem jest moment chrztu. Sakrament ten jest łaską, i to łaską szczególną. Wszyscy, którzy tę łaskę otrzymali, rzeczywiście otrzymali zdolność i moc podobania się Bogu i są przez to zobowiązani do postępowania wedle chrztu $^{2}$. Nie jest więc przesadą twierdzenie, że celem całego życia chrześcijanina jest dochodzenie do poznania radykalnej nowości płynącej z tego sakramentu. Poznanie to zaś jest ukierunkowane na wypełnienie życiowych obowiązków zgodnie $\mathrm{z}$ otrzymanym od Boga powołaniem³. Refleksja nad chrztem pozwala zatem odczytać najpierw samą istotę życia moralnego, które może być określone moralnością chrztu, a następnie także konkretne obowiązki moralne płynące $\mathrm{z}$ tego sakramentu, które dotyczą zarówno osobistego uświęcenia i relacji z Bogiem, jak i życia we wspólnocie, w tym także we wspólnocie Kościoła ${ }^{4}$.

Chrzest słusznie bywa nazywany bramą - bramą do zbawienia, do życia wiecznego, do Kościoła, bramą życia w Duchu, bramą do innych sakramentów ${ }^{5}$. Papież Franciszek nazwał go „bramą nadziei”6. Idąc jeszcze dalej, w pewnym sensie można go nazwać także bramą chrześcijańskiej moralności.

${ }^{1}$ Taki, dość rozpowszechniony wśród chrześcijan, sposób postępowania i nauczania zdecydowanie krytykuje papież Franciszek. Czyni to w wielu miejscach, jednak szczególny charakter ma pod tym względem homilia z 19 czerwca 2013 r., niemal w całości poświęcona krytyce postaw, które Papież określa takimi terminami, jak: „hipokryci kazuistyki”, „intelektualiści kazuistyki”, „bezduszni etycy bez dobroci”.

${ }^{2}$ Por. JAN PAWEŁ II, List apostolski na 1600-lecie śmierci św. Bazylego Patres Ecclesiae (2.01.1980).

${ }^{3}$ Por. JAN PAWEŁ II, Adhortacja apostolska Christifideles laici, nr 10.

${ }^{4} \mathrm{~W}$ zamierzeniu autora niniejszy artykuł będzie poświęcony wyłącznie kwestiom fundamentalnym. Pomija on natomiast omówienie szczegółowych obowiązków moralnych płynących z chrztu.

${ }^{5}$ Por. SOBÓR WATYKAŃSKi II, Konstytucja dogmatyczna o Kościele Lumen gentium, nr 14; TENŻE, Dekret o działalności misyjnej Kościoła Ad gentes divinitus, nr 7; Katechizm Kościoła Katolickiego, nr 950, 1213; Kodeks Prawa Kanonicznego, kan. 849.

${ }^{6}$ Por. Kat. Chrzest brama nadziei (2.08.2017). 
Takie określenie zdaje się sugerować najnowszy dokument Międzynarodowej Komisji Teologicznej o relacji między wiarą a sakramentami ${ }^{7}$. Podkreślając dialogalny charakter znaków sakramentalnych, dokument ten mówi o chrzcie jako o sakramencie, który wprowadzając człowieka w pełnię życia w Chrystusie i we wspólnotę Kościoła, wzmacnia go tak, aby dzięki łasce był on w pewien sposób „sakramentem Chrystusa” poprzez swoje życie. W tym sensie chrzest jest bramą, ponieważ dając udział w śmierci i zmartwychwstaniu Chrystusa, wprowadza człowieka w aktywne uczestnictwo w życiu Kościoła ${ }^{8}$. To aktywne uczestnictwo zaś realizuje się nie tylko w kulcie, ale również w życiu moralnym. Tym samym dokument Komisji inspiruje do poszukiwania samych podstaw moralności chrześcijańskiej jako moralności, na którą otwiera chrzest konstytuujący sam podmiot działania moralnego, oraz do poszukiwania elementów specyficznych tej moralności, odróżniających ją od moralności innych typów ${ }^{9}$.

\section{BIBLIJNY OBRAZ CZŁOWIEKA OCHRZCZONEGO JAKO PODMIOTU MORALNOŚCI}

Dokument Międzynarodowej Komisji Teologicznej, którego oficjalny tytuł brzmi: The Reciprocity Between Faith and Sacraments in the Sacramental Economy, przedstawia relację między wiarą a sakramentami. Czyni to w specyficznym współczesnym kontekście, który wyznacza zjawisko swoistej separacji wiary i sakramentów. $Z$ jednej bowiem strony wielu chrześcijan próbuje przeżywać swoją wiarę bez odniesienia do sakramentów. Z drugiej zaś, o sakramenty proszą ludzie, którzy nie mają wiary. W takim właśnie kontekście dokument

${ }^{7}$ Dokument ten nosi tytuł „Relacja między wiarą a sakramentami w ekonomii sakramentalnej” (tłum. własne). Został on zaaprobowany przez papieża Franciszka 19 grudnia 2019 r. i opublikowany 3 marca 2020 r. W niniejszym artykule przyjęto tytuł „Wiara i sakramenty”, pod którym najczęściej jest on komentowany w języku polskim. Warto bowiem zaznaczyć, że dotychczas nie istnieje jego oficjalne polskie tłumaczenie.

${ }^{8}$ Por. nr 73.

${ }^{9}$ Należy zauważyć, że tak rozumiany moralny wymiar sakramentu chrztu stosunkowo często pojawia się we współczesnym nauczaniu Kościoła (por. cykl sześciu katechez o chrzcie papieża Franciszka, wygłoszonych między 11 kwietnia a 16 maja 2018 roku), a co za tym idzie jest przedmiotem sporej ilości opracowań. Por. np. A. NIEMIRA, Moralny wymiar sakramentu chrztu w świetle encykliki „Lumen fidei” papieża Franciszka, „Teologia i Człowiek” 2017, nr 3, s. 11-23. Również sam autor podejmował tę problematykę we wcześniejszej publikacji. Por. T. ZADYKOwICZ, Chrystopraksyzm doktryny chrzcielnej, „Teologia i Człowiek” 2016, nr 3, s. $55-76$. 
podkreśla nierozerwalną więź łączącą wiarę i sprawowanie sakramentów, zaś uzasadnienie tego związku jest głęboko biblijne i historiozbawcze.

Choć, z racji duszpasterskich, Komisja najwięcej miejsca poświęca małżeństwu ${ }^{10}$, to fundamentalne znaczenie przypisuje sakramentowi chrztu, ponieważ to w nim zostaje zainicjowany dialog Boga z człowiekiem, a wiara, która stanowi odpowiedź na inicjatywę Boga, zawsze będzie się odnosiła ostatecznie do tego pierwszego momentu. Dokument zatem, choć nie ma charakteru ściśle teologicznomoralnego, i nie zajmuje się wyłącznie chrztem, zdaje się prezentować pewną wizję moralności opartej na chrzcie postrzeganym jako fundament, początek, brama.

Syntezę biblijnego nauczania na temat związku między chrztem a wiarą, chrztem a życiem moralnym dokument przedstawia głównie w punkcie 81, choć szczegółowe aspekty tego zagadnienia pojawiają się także w wielu innych miejscach. Z całości tekstu przebija jasne przesłanie, że moralność chrześcijańska jest nie tyle moralnością prawa, ile najpierw moralnością daru. Jej źródłem jest bowiem „,nowe życie w Chrystusie”, udzielone człowiekowi w sposób absolutnie niezasłużony podczas chrztu, które to życie jest równocześnie wewnętrznym prawem moralnym ${ }^{11}$. Chrzest jest tym, co wyróżnia chrześcijanina. Z niego też wypływa specyfika moralności chrześcijańskiej, która ma ujawniać to, kim jest ten, kto się powtórnie narodził z wody i Ducha. To zatem, co chrześcijanin powinien czynić, wynika z tego, kim jest. Kiedy więc mówi się o moralności chrztu, akcent pada na sam podmiot moralny, na jego wewnętrzną przemianę. Konkretne zaś czyny są postrzegane jako zewnętrzna manifestacja podmiotu, jako objawienie na zewnątrz tego bogactwa obdarowania, które stało się udziałem człowieka podczas chrztu.

Kluczową rolę chrztu, jako początku i drogowskazu życia moralnego, wskazuje św. Paweł, zwłaszcza w Liście do Rzymian (rozdz. 6). Sylwetkę chrześcijanina określa według niego nade wszystko „nowość”, którą człowiek osiąga w tym sakramencie. Szczegółowe aspekty tej nowości św. Paweł opisuje, posługując się takimi terminami, jak: „nowe stworzenie” (por. Ga 6,15; Ef 4,24; 2Kor 5,17), „nowe życie” (Rz 6,4), „,nowy człowiek” (Ef 4,24). Apostoł, mówiąc o ochrzczonych, nazywa ich również „świętymi” (por. Rz 1,7; 1Kor 1,2; 2Kor 1,1), „dziećmi (synami) Bożymi” (Flp 2,15), ,zanurzony-

\footnotetext{
${ }^{10}$ Por. nr 132-182.

${ }^{11}$ Por. także: J. NAGÓRNY, Pareneza chrzcielna - nauka ptynaca z chrztu św., w: Ks. Janusz Nagórny, Sakramenty $w$ życiu moralnym chrześcijanina, red. K. Jeżyna, J. Gocko, W. Rzepa, Lublin: Wydawnictwo KUL 2011, s. 21.
} 
mi w Chrystusie” (Rz 6,3), „zrośniętymi z Nim” (Rz 6,5), „oświeconymi” (Ef 5,14), „obmytymi”(Tt 3,5; 1Kor 6,11).

Odwołując się do tego nauczania, już Sobór Watykański II podkreślał: „Wyznawcy Chrystusa, powołani przez Boga i usprawiedliwieni w Panu Jezusie nie ze względu na swe uczynki, lecz wedle postanowienia i łaski Bożej, w chrzcie wiary stali się prawdziwie synami Bożymi i uczestnikami natury Bożej, a przez to rzeczywiście świętymi" ${ }^{12}$. W tym samym duchu wypowiada się Komisja Teologiczna, która w wielu miejscach podkreśla uświęcający charakter sakramentów ${ }^{13}$, a sakrament chrztu nazywa „sakramentem nowego życia w Chrystusie" ${ }^{\prime 14}$. Świętość to przynależność do Boga. Ta przynależność urzeczywistnia się w chrzcie, kiedy Chrystus przyjmuje na własność ludzką istotę, by uczynić ją „uczestnikiem Boskiej natury” (por. 2P 1,4), która jest w niej dzięki Wcieleniu. Chrystus staje się w ten sposób prawdziwie ,życiem duszy”. Sakramentalne zaś znamię, wyryte w człowieku przez chrzest, jest znakiem i węzłem poświęcenia się Bogu ${ }^{15}$.

Chrzest jest pierwszą i podstawową konsekracją osoby ludzkiej, przez którą zostaje ona oddana Ojcu w Jezusie Chrystusie, mocą działającego w tym sakramencie Ducha Świętego ${ }^{16}$. Przez chrzest człowiek staje się dzieckiem Boga w Jego Jednorodzonym Synu. Każdy chrześcijanin, obmyty wodą ze świętego źródła, słyszy głos, który niegdyś rozległ się nad brzegiem Jordanu: „Tyś jest mój Syn umiłowany, w Tobie mam upodobanie” (Łk 3,22) i wtedy wie, że został przyłączony do umiłowanego Syna, sam stając się synem przybranym (por. Ga 4,4-7) i bratem Chrystusa. W ten sposób - jak mówi Jan Paweł II - w dziejach każdego człowieka dopełnia się przedwieczny zamysł Ojca: „tych, których od wieków poznał, tych też przeznaczył na to, by się stali na wzór obrazu Jego Syna, aby On był pierworodnym między wielu braćmi" (Rz 8,29) ${ }^{17}$. Duch Święty kształtuje w chrześcijaninie podobieństwo do Jezusa, przekształca go na Jego obraz, czyni go nowym stworze-

${ }^{12}$ Konstytucja dogmatyczna o Kościele Lumen gentium, nr 40.

${ }^{13}$ Por. np. nr 31, 57, 70, 111, 124, 133, 137, 141.

${ }^{14}$ Por. nr 84.

${ }^{15}$ Por. Międzynarodowa Komisja Teologiczna, Wiara i sakramenty, nr 31. Por. także: Jan Pawet II, Kat. Powołanie świeckich do świętości (24.11.1993), nr 2; FranciszeK, Kat. Znamie przynależności na zawsze (9.05.2018).

16 Por. K. WASIUTYŃSKA, Chrzest jako pierwotna konsekracja. U źródet powszechnego powotania chrześcijan do świętości, „Teologia i Moralność” 10(2015), nr 1, s. 8.

17 Por. Adhortacja apostolska Christifideles laici, nr 11. Por. także: FrANCISZEK, Kat. Znamię przynależności na zawsze (9.05.2018). 
niem. W sakramencie chrztu Chrystus dokonuje nowego stworzenia (por. Ef 2,1-10; Tyt 3,5). Odtąd człowiek zostaje stworzony na nowo w Chrystusie Jezusie $^{18}$.

Nowe stworzenie inicjuje w człowieku stan synostwa Bożego. Przez chrzest Chrystus dokonuje usynowienia wierzących. Rozpoczyna się wówczas nowe życie w Chrystusie, poprzez które człowiek staje się dzieckiem Bożym w sensie ewangelicznym. Daje temu wyraz Pawłowy List do Rzymian: „Czyż nie wiadomo wam, że my wszyscy, którzyśmy otrzymali chrzest zanurzający w Chrystusa Jezusa, zostaliśmy zanurzeni w Jego Śmierć? Zatem przez chrzest zanurzający nas w śmierć zostaliśmy razem z Nim pogrzebani po to, abyśmy i my wkroczyli w nowe życie - jak Chrystus powstał z martwych dzięki chwale Ojca. Jeżeli bowiem przez śmierć podobną do Jego śmierci, zostaliśmy $\mathrm{z}$ Nim złączeni $\mathrm{w}$ jedno, to tak samo będziemy z Nim złączeni w jedno przez podobne zmartwychwstanie. Tak i wy rozumiejcie, że umarliście dla grzechu, żyjecie zaś dla Boga w Chrystusie Jezusie" (Rz 6,3-5.11). $\mathrm{Na}$ tym polega tajemnica chrztu jako początku nowego życia, udzielonego przez „,nowego Człowieka”, Chrystusa, tym, którzy w sposób sakramentalny zostają włączeni w Jego jedyne Ciało, jakim jest Kośció $1^{19}$. Poprzez chrzest następuje współumieranie z Nim, zjednoczenie w Jego śmierci i zmartwychwstaniu (por. Rz 7,4) ${ }^{20}$.

Chrzest jest powtórnym, nowym narodzeniem, dzięki któremu syn człowieka staje się synem Boga. Bóg dopuszcza człowieka do uczestnictwa w odkupieniu. Napełnia go „nowym życiem”. Włącza do wspólnoty świętych. Otwiera przed nim dostęp do wszystkich pozostałych sakramentów, które prowadzą życie chrześcijańskie do pełni rozwoju ${ }^{21}$. Termin „powtórne narodzenie” wskazuje - zdaniem Ratzingera - najbardziej podstawową prawdę człowieczeństwa. Człowiekowi nie wystarcza bowiem samo narodzenie, samo biologiczne zaistnienie. Samo narodzenie bez odrodzenia byłoby nieszczęściem. Do pełnego wzrastania i życia człowiek potrzebuje sensu i miłości. Chrzest - jak mówi Ratzinger - jest takim właśnie uprzedzającym darem sensu i darem

18 Por. Międzynarodowa Komisja Teologiczna, Wiara i sakramenty, nr 24.

${ }^{19}$ Por. JAN PAwEe II, Kat. Świadectwo życia w Chrystusie w Kościele - wspólnocie prorockiej (20.05.1992), nr 2. Por. także: Międzynarodowa Komisja TeOlogiczna, Wiara i sakramenty, nr 187.

${ }^{20}$ Por. Międzynarodowa Komisja TeOlogiczna, Wiara i sakramenty, nr 66.

${ }^{21}$ Por. Jan PAWE€ II, Kat. Chrzest w Kościele - wspólnocie kaptańskiej i sakramentalnej (25.03.1992), nr 2. 
miłości, która jest mocniejsza niż śmierć; która uzasadnia życie i czyni je sensownym ${ }^{22}$.

Istotę obdarowania w sakramencie chrztu dokument Komisji Teologicznej oddaje również za św. Pawłem terminem „zanurzenie” (por. Rz 6,1-14) , $^{23}$. Chrzest zanurza w Chrystusa, a jeszcze dokładniej - w Jego śmierć, pogrzeb i zmartwychwstanie. Jest zatem śmiercią chrześcijanina, podobną do śmierci Chrystusa, dzięki której zrasta się on z Chrystusem w jedność. Tę samą jedność sprawia wspólne z Nim zmartwychwstanie. Chrzest oznacza więc i sprawia mistyczne, ale rzeczywiste wcielenie w ukrzyżowane i zwycięskie ciało Jezusa. Przez ten sakrament Jezus zanurza człowieka w swoją śmierć, aby zanurzyć go w swoim zmartwychwstaniu (por. Rz 6,3-5), uwalnia go ze „starego człowieka” i przyobleka w ,człowieka nowego”, czyli w samego siebie: „Wy wszyscy - głosi św. Paweł - którzy zostaliście ochrzczeni w Chrystusie, przyoblekliście się w Chrystusa" (Ga 3,27; por. Ef 4,22-24; Kol 3,9-10). Stąd „wszyscy razem tworzymy jedno ciało w Chrystusie” (Rz 12,5) ${ }^{24}$. Złączenie chrześcijanina w śmierci i zmartwychwstaniu Chrystusa św. Paweł nazywa też zrośnięciem: jak szczep zrośliśmy się z Nim. Jest to końcowy etap, gdy przeszczepiona gałązka korzysta już z soków pnia i żyje wspólnym z nim życiem (por. J 15,1-6).

Obraz przemiany dokonanej w chrzcie starożytny hymn chrześcijański wyraża w słowach: „Zbudź się, o śpiący, i powstań z martwych, a zajaśnieje Ci Chrystus" (por. Ef 5,14). Chrzest jest sakramentem oświecenia (por. Hbr 6,4; 10,32), dzięki któremu chrześcijanin - jak przypomina dokument Komisji - żyje w świetle, jest synem światłości ${ }^{25}$. Chrzest zwany jest również kąpielą (por. Ef 5,26; Tt 3,5). Zbawcza miłość Chrystusa do ludzi oczyszcza ich z grzechów i uświęca przez obmycie wodą połączone ze słowem. „Kąpiel” była w starożytnej literaturze chrześcijańskiej synonimem chrztu. Zanurzenie się $\mathrm{w}$ wodzie, połączone ze słowem, tj. formułą sakramentalną, przedstawia udział w śmierci Chrystusa, odpuszczenie grzechów, śmierć starego człowieka, „człowieka zmysłowego” (por Rz 6,4). Wynurzenie zaś symbolizuje wskrzeszenie do życia nadprzyrodzonego, którego uwieńczeniem będzie zmar-

${ }^{22}$ Por. Chrzest jako poczatek i drogowskaz życia chrześcijańskiego, w: J. RATZINGER, Opera omnia, t. 8, cz. 2: Kościót - znak wśród narodów. Pisma eklezjologiczne i ekumeniczne, red. K. Góźdź, M. Górecka, Lublin: Wydawnictwo KUL 2013, s. 1233. O sensie „,nowego narodzenia” kilkakrotnie mówi również dokument Komisji. Por. nr 81, 84, 88, 89.

${ }^{23}$ Por. nr 81.

${ }^{24}$ Por. JAN PAWEe II, Adhortacja apostolska Christifideles laici, nr 12.

25 Por. Międzynarodowa Komisja Teologiczna, Wiara i sakramenty, nr 80, 88. 
twychwstanie ciała. Ta przemiana - jak podkreśla dokument Wiara i sakramenty - dokonuje się przez wiarę w moc Boga, którą wyznawał człowiek przyjmujący chrzest ${ }^{26}$. Na określenie chrztu św. używa się także słowa „obmycie" (por. 1Kor 6,11; Dz 22,16; Ef 5,26; Tt 3,5; Hbr 10,22), zaś ochrzczonych nazywa się „uświęconymi” i „usprawiedliwionymi”, by podkreślić wewnętrzną przemianę i nową sytuację, w jakiej znajduje się człowiek po chrzcie. Przez chrzest, czyli duchowe obrzezanie (por. Kol 2,11-12), pociagające za sobą odnowienie całego zepsutego człowieka, ludzie uczestniczą w nowym życiu Chrystusa zmartwychwstałego.

Skutek chrztu wyraża również, przypominana po wielekroć przez dokument Komisji, formuła „chrzcić kogoś w czyjeś imię” (gr. eis to onoma) (por. Mt 28,19), która znaczy tyle, co: poświęcić komuś, oddawać w czyjąś opiekę. Wyraża ona przynależność i konsekrację, poświęcenie Bogu lub Chrystusowi. Imię oznacza w Piśmie Świętym osobę, zwłaszcza osobę Boga. Tak więc chrzest poświęca człowieka i czyni go własnością trzech osób Trójcy Świętej. Umacnia on wewnętrznego człowieka (por. Ef 3,16; Rz 7,22; 2Kor 4,16), czyli „nowego człowieka” (por. Ef 2,15; Kol 3,9-10), odrodzonego w sakramencie chrztu w przeciwieństwie do człowieka zewnętrznego i starego. Pomiędzy zewnętrznym a wewnętrznym człowiekiem toczy się walka (por. Rz 7,22-25), w której „,nowy człowiek” otrzymuje pomoc Ducha Świętego. Wyrażenie: „stary człowiek” (por. Kol 3,9; Ef 4,22) określa postępowanie człowieka przed chrztem, które kierowane jest namiętnościami i podobne do postępowania pogan nie znających Boga (Ef 4,17-19). Podobnie jak chrzest, również chrześcijańskie działanie powinno dokonywać się ,,w imię” Ojca i Syna i Ducha Świętego"27, i podobnie jak chrzest, prowadzi ono do zbawienia.

\section{ISTOTA MORALNOŚCI WYNIKAJĄCEJ Z CHRZTU}

Biblijne określenia kondycji człowieka ochrzczonego, takie jak: „nowy człowiek”, „nowe stworzenie”, „,nowe życie”, zawierają najpierw treść ontologiczną, a dopiero potem etyczną. W określeniach tych bowiem należy dopatrywać się zasadniczej przemiany samego człowieka, a nie tylko jego postępowania. W sakramencie chrztu dokonuje się wszczepienie człowieka w Chrystusa a Duch Święty wyciska znamię przynależności do Boga i dlatego sakra-

\footnotetext{
26 Por. tamże, nr 66.

27 Por. tamże, nr 2.
} 
ment ten może być nazwany fundamentem, a nawet bramą życia moralne$\mathrm{go}^{28}$. Jest to bowiem moment, w którym człowiek, otrzymując dar nowego życia, zostaje upodobniony do Chrystusa i uzdolniony do przymierza. Chrzest, zapoczątkowując w człowieku nowe życie, ustanawia wspólnotę z Bogiem, która ma być potwierdzana w ciągu całego życia, także poprzez wypełnianie konkretnych nakazów moralnych ${ }^{29}$. Postępowanie godne chrześcijanina jest więc konsekwencją zasadniczej przemiany dokonanej podczas wspólnej śmierci i zmartwychwstania z Chrystusem i konsekwencją przejścia przez bramę chrztu $^{30}$.

Podczas chrztu dokonuje się istotna zmiana w osobowości człowieka. Między nim a Bogiem tworzy się „święta więź" 31. Stąd też wynika skutek dotyczący moralności chrześcijańskiej - podczas chrztu „stary człowiek”, który popełniał grzechy, został ukrzyżowany, dzięki czemu uwolnił się od grzechu. Ochrzczeni są więc zjednoczeni w akcie zbawczym Chrystusa w Jego śmierci i zmartwychwstaniu. Stają się pogrzebani z Chrystusem w tym celu, by razem z Nim zmartwychwstać, czyli uczestniczyć w Jego nowym życiu, chwale, królestwie i dziedzictwie. Równocześnie korzystają z zasług śmierci Chrystusa, otrzymując odpuszczenie grzechów ${ }^{32}$. Dar nowego życia jest więc jednocześnie zobowiązaniem wynikającym z sakramentu chrztu. Ktoś, kto już umarł dla grzechu (Rz 6,2), jest jednocześnie wezwany do nieustannej walki z grzechem (Rz 6,12-14). Ochrzczony już ,przyoblekł się w Chrystusa" (Ga 3,27), ale ma się wciąż w Niego przyoblekać (Rz 13,14). Z faktu, że chrześcijanie przeszli ze śmierci do życia (Kol 3,1-4), wynika, że są powołani do nieustannego uśmiercania w sobie tego, co zadawałoby kłam nowemu życiu (Kol 3,5-17) ${ }^{33}$.

Chrzest jest tym momentem, gdy człowiek wchodzi w przymierze z Bogiem odpowiadając na Jego dar przymierza. Zapoczątkowuje on przymierze, które w ciągu życia będzie musiało być nieustannie pogłębiane, co zresztą będzie dokonywało się dzięki pozostałym sakramentom. Chrzest jest więc pierwszą odpowiedzią człowieka na Bożą inicjatywę przymierza. Z przymierzem - jak na to wskazuja biblijne opisy zawarcia przymierzy - nierozerwalnie związane jest prawo (przykazania). Sakrament chrztu, który jest urzeczy-

\footnotetext{
28 Por. FRANCISZEK, Kat. Fundament życia chrześcijańskiego (11.04.2018).

29 Por. MiĘdzynarodowa Komisja TeOlogiczna, Wiara i sakramenty, nr 54.

30 Por. tamże, nr 38.

31 Por. tamże, nr 59c.

32 Por. tamże, nr 81.

33 Por. FRANCISZEK, Kat. Chrzest daje site do walki (25.04.2018).
} 
wistnieniem zawarcia przymierza, również zawiera w sobie prawo. To prawo zostaje wpisane w sercu, zaś jego odczytanie i realizacja pozostanie całożyciowym zadaniem człowieka ochrzczonego.

Sakrament chrztu, podobnie jak wszystkie pozostałe sakramenty, nie może być traktowany jedynie jako pomoc w życiu moralnym. W takim przypadku bowiem życie to pozostawałoby w absolutnej gestii człowieka i sprowadzałoby się wyłącznie do jego aktywności. Tymczasem szczególna rola chrztu polega właśnie na tym, że przekształca on wewnętrznie człowieka powołanego do przymierza z Bogiem, wprowadza go w nowy obszar i w nowy wymiar życia $^{34}$, doskonali jego wiarę ${ }^{35}$ i doskonali całe życie moralne. Ten, kto doświadcza wewnętrznej przemiany poprzez udział w tajemnicy paschalnej Chrystusa, jest równocześnie wezwany do dawania świadectwa o darze otrzymanym poprzez życie uwielbienia, które wypływa z wiary Kościoła ${ }^{36}$.

Dar Boga, udzielony człowiekowi w sakramencie chrztu, nie oznacza jednak jakiegoś determinizmu w życiu moralnym. Przeciwnie, ten dar domaga się wolnego przyjęcia i współpracy z nim. Chrześcijańskie życie moralne ma więc wynikać z sakramentu chrztu, ma być potwierdzeniem i przedłużeniem w działaniu tego, co dokonało się na chrzcie św. W tym sensie określenie moralności chrześcijańskiej jako moralności chrzcielnej jest w pełni uzasadnione. Pozwala ono bowiem zwrócić uwagę nie tylko na konkretne czyny, ale także na sam podmiot moralności, czyli na człowieka, który dopiero ma stać się autorem czynów ${ }^{37}$.

W sakramencie chrztu - jak podkreślono - dokonują się duchowe narodziny do nowego życia, wcielenie w ukrzyżowane i zwycięskie ciało Jezusa. Dzięki temu sakramentowi człowiek żyje życiem Chrystusa zmartwychwstałego. Ten soteriologiczny wymiar chrztu św. Paweł wyraża słowami: „my wszyscy, którzyśmy otrzymali chrzest zanurzający w Chrystusa Jezusa, zostaliśmy zanurzeni w Jego śmierć" (Rz 6,3). Jednocześnie Apostoł podkreśla wynikające z tego zadania: ,abyśmy i my wkroczyli w nowe życie - jak Chrystus powstał z martwych" (Rz 6,3). Choć wejście w nowe życie i nowe przymierze nie jest dziełem człowieka, ale darem łaski, to domaga się ono od ochrzczonego odpowiedzi w postaci konkretnych postaw moralnych. Są one

${ }^{34}$ Por. J. RATZINGER, Chrzest jako poczatek i drogowskaz życia chrześcijańskiego, s. 1232.

35 Por. Międzynarodowa Komisja Teologiczna, Wiara i sakramenty, nr 2.

36 Por. tamże, nr 79d. Por. także: FrANCISZEK, Kat. Znak chrześcijańskiej wiary (18.04.2018).

${ }^{37}$ Por. J. NAGÓRnY, Chrzest - nowe życie w moralności Nowego Przymierza, w: Ks. Janusz Nagórny, Sakramenty w życiu moralnym chrześcijanina, s. 31. 
zawarte w przyrzeczeniach chrzcielnych. Ich wypełnienie sprawia, że nowa godność człowieka, która jest darem, znajduje swoje dopełnienie w „nowości” życia moralnego człowieka ochrzczonego ${ }^{38}$.

Moralność chrześcijańska wynika z chrztu, bo jest on źródłem nowego życia. W sakramencie tym rozpoczyna się życie Chrystusa w chrześcijaninie. Chrzest i związane z nim odpuszczenie grzechów wprowadza człowieka na drogę zbawienia i uświęcenia, która będzie prowadzić przez szczegółowe wybory. Z kolei wybory te noszą na sobie znamię, pieczęć sakramentu chrztu $^{39}$. Będą one odpowiedzią na sakramentalne wydarzenie Objawienia, którego świadkiem jest Kościół ${ }^{40}$. W ten sposób chrzest, który ustanawia nowe stworzenie i jest nowym narodzeniem (J 3,3-5), uzdalnia do życia życiem chrześcijańskim, nowym życiem ${ }^{41}$.

Taką wizję życia moralnego, jako życia związanego z chrztem, głoszono w Kościele od początku ${ }^{42}$. Dziś jednak, gdy tak łatwo dokonuje się rozdzielania życia sakramentalnego i życia moralnego, warto nie tylko przypominać zobowiązania, jakie płyną z przyjętych darów, ale wracać do samych źródeł tych zobowiązań i z nich wyprowadzać obowiązek wiary żywej, tzn. wiary owocującej uczynkami miłości. Wprawdzie - jak twierdzi cytowany przez dokument Komisji Tomasz z Akwinu - chrzest (podobnie zresztą jak małżeństwo) nie wymagają wiary aż tak nasyconej miłością jak Eucharystia, bowiem owocne przyjęcie komunii zakłada nie tylko wiarę w prawdziwą obecność Chrystusa pod postaciami eucharystycznymi, ale także wolę zachowania więzi jedności z Chrystusem i Jego członkami ${ }^{43}$. Jednak takiego owocowania w uczynkach wymaga również chrzest. Przyjęcie bowiem sakramentu, które jest publicznym aktem kościelnym, i w którym istotną rolę odgrywa strona zewnętrzna i widzialna, domaga się wyrażenia na zewnątrz intencji, wyznania wiary, wierności obietnicy chrztu w życiu ${ }^{44}$.

${ }^{38}$ Por. A. OLCZYK, Chrzest, w: Jan Pawet II. Encyklopedia nauczania moralnego, red. J. Nagórny, K. Jeżyna, Radom: Polskie Wydawnictwo Encyklopedyczne POLWEN 2005, s. 106.

${ }^{39}$ Por. Międzynarodowa Komisja Teologiczna, Wiara i sakramenty, nr 2.

40 Por. tamże, nr 60.

${ }^{41}$ Por., nr 81.

42 Potwierdzeniem tego są często przywoływane przez dokument Wiara i sakramenty wypowiedzi Ojców Kościoła i pisarzy wczesnochrześcijańskich.

${ }^{43}$ Por. Międzynarodowa Komisja Teologiczna, Wiara i sakramenty, nr 63.

${ }^{44}$ Por. tamże, nr 64. Por. także FrANCISZEK, Kat. Wyrzeczenie się szatana $i$ wyznanie wiary (2.05.2018). 
Dokument Międzynarodowej Komisji Teologicznej przypomina, że z chrztu wynika konieczność wiary, która nie sprowadza się do ogólnego przyjęcia zbawczej woli Boga, ale obejmuje też konkretne wydarzenia zbawcze: wcielenie, mękę i zmartwychwstanie Chrystusa ${ }^{45}$. Można w tym dostrzec podkreślenie roli wyboru podstawowego, ale także dowartościowanie konkretnych, szczegółowych czynów w życiu moralnym. Z przyjętego sakramentu chrztu wynika bowiem obowiązek nie tylko ogólnego ukierunkowania swojego życia, ale także coraz intensywniejszej chrystyfikacji swojego postępowania ${ }^{46}$. Jak mówi dokument, życie chrześcijanina należy rozumieć jako stopniowe rozwijanie się tego, co zapoczątkowuje dar Ducha Świętego w chrzcie. Wiara może i musi rosnaćc. Ukierunkowanie na ten wzrost zawiera się już w samej decyzji o chrzcie ${ }^{47}$. Rozwój ten jest ukierunkowany na ostateczne oddanie życia Ojcu na wzór Jezusa ${ }^{48}$. Rozpoczyna się on pewnym ogólnym ukierunkowaniem własnego życia, które to ukierunkowanie - jak przypomina dokument - starożytna liturgia Kościoła wyrażała spojrzeniem ochrzczonych z zachodu na wschód $\mathrm{d}^{49}$. To spojrzenie wyrażało również gotowość do wzrostu w wierze i innych postawach moralnych.

Chrześcijańskie życie moralne rozpoczyna się od włączenia w ekonomię sakramentalną ${ }^{50}$. Chrzest jest początkiem pielgrzymki, której kulminacją jest jedynie Eschaton ${ }^{51}$. Życie na miarę przyjętego sakramentu, życie ,jako ochrzczonego", wskazuje na jego specyfikę, specjalną formę. Podkreślenie związku chrztu z życiem moralnym pozwala przezwyciężyć tzw. automatyzm sakramentalny, widoczny zresztą nie tylko w odniesieniu do sakramentu chrztu.

Teologia chrztu zawiera w sobie zarówno indykatyw (to, co stanowi jego dogmatyczną treść), jak i imperatyw (zadania wynikające z tego sakramentu). Niedowartościowanie któregokolwiek z tych elementów prowadzi do wypacze-

\footnotetext{
45 Por. nr 54.

46 Por. Międzynarodowa Komisja Teologiczna, Wiara i sakramenty, nr 79d.

${ }^{47}$ Por. tamże, nr 86.

${ }^{48}$ Por. tamże, nr 83. Por. także: FRANCISZEK, Wychowanie chrześcijańskie jest prawem

${ }^{49}$ Por. Międzynarodowa Komisja Teologiczna, Wiara i sakramenty, nr 84.

${ }^{50}$ Por. tamże, nr 187.

${ }^{51}$ Por. tamże, nr 122.
} dzieci (16.05.2018). 
nia samej wizji chrześcijańskiego życia moralnego, które traktuje się bądź jako pozbawiony doktrynalnych podstaw system przepisów do zachowania, bądź jako samą doktrynę i ewentualnie kult, który nie posiada istotnego wpływu na codzienne wybory. Tymczasem integralne spojrzenie na chrzest, jako dar Boga i zarazem źródło zobowiązań, pozwala odczytać samą istotę moralności chrześcijańskiej, która polega na współdziałaniu z Bogiem, oraz konkretne, specyficzne dla tego sakramentu zobowiązania, jakie zaciąga człowiek przyjmujący ten sakrament. Zobowiązania te płyną z samej natury darów, jakie niesie ze sobą chrzest.

Zarówno samo sprawowanie chrztu, jak i różnego rodzaju celebracje nawiązujące do tego sakramentu (Wigilia Paschalna, rocznice chrztu itp.) powinny przypominać to wszystko, co dokonuje się podczas tego sakramentu, a co jednocześnie inicjuje drogę życia moralnego. Powinna to być okazja do podkreślenia relacyjnego i dialogalnego charakteru moralności chrześcijańskiej oraz osobistego i wspólnotowego (eklezjalnego) wymiaru darów i zobowiązań. Przygotowanie do przyjęcia chrztu, sama jego celebracja oraz częste powracanie do tego źródła życia moralnego nie mogą być pozbawione pouczeń dotyczących postępowania zgodnego z przyjętym chrztem. Te zaś staną się w pełni zrozumiałe, jeśli osadzi się je w samej treści tego sakramentu.

\section{BIBLIOGRAFIA}

FRANCISZEK, Homilia (19.06.2013).

FRANCISZEK, Kat. Chrzest bramą nadziei (2.08.2017).

FrANCISZEK, Kat. Chrzest daje siłę do walki (25.04.2018).

FRANCISZEK, Kat. Fundament życia chrześcijańskiego (11.04.2018).

FRANCISZEK, Kat. Wyrzeczenie się szatana i wyznanie wiary (2.05.2018).

FRANCISZEK, Kat. Znak chrześcijańskiej wiary (18.04.2018).

FRANCISZEK, Kat. Znamię przynależności na zawsze (9.05.2018).

FRANCISZEK, Wychowanie chrześcijańskie jest prawem dzieci (16.05.2018).

JAN PAWEE II, Adhortacja apostolska Christifideles laici (Watykan, 30.12.1988).

JAN PAWEŁ II, Kat. Chrzest w Kościele - wspólnocie kapłańskiej i sakramentalnej (25.03. 1992).

Jan PaweŁ II, Kat. Powołanie świeckich do świętości (24.11.1993).

JAN PAWEe II, Kat. Świadectwo życia w Chrystusie w Kościele - wspólnocie prorockiej (20.05.1992).

Jan PAWEe II, List apostolski na 1600-lecie śmierci św. Bazylego Patres Ecclesiae (2.01.1980).

Katechizm Kościoła Katolickiego, Poznań: Pallottinum 1994.

Kodeks Prawa Kanonicznego, Poznań: Pallottinum 1984.

Międzynarodowa Komisja TeOlogicznA, Wiara i sakramenty (3.03.2020). 
NAGÓRnY J., Chrzest - nowe życie w moralności Nowego Przymierza, w: Ks. Janusz Nagórny, Sakramenty w życiu moralnym chrześcijanina, red. K. Jeżyna, J. Gocko, W. Rzepa, Lublin: Wydawnictwo KUL 2011, s. 29-44.

NAGÓRNY J., Pareneza chrzcielna - nauka płynąca z chrztu św., w: Ks. Janusz Nagórny, Sakramenty w życiu moralnym chrześcijanina, s. 21-27.

NIEMIRA A., Moralny wymiar sakramentu chrztu w świetle encykliki Lumen fidei papieża Franciszka, „Teologia i Człowiek” 2017, nr 3, s. 11-23.

OlCZYK A., Chrzest, w: Jan Paweł II. Encyklopedia nauczania moralnego, red. J. Nagórny, K. Jeżyna, Radom: Polskie Wydawnictwo Encyklopedyczne POLWEN 2005, s. 104-107.

RATZINGER J., Chrzest jako początek i drogowskaz życia chrześcijańskiego, w: J. RATZINGER, Opera omnia, t. 8, cz. 2: Kościół - znak wśród narodów. Pisma eklezjologiczne i ekumeniczne, red. K. Góźdź, M. Górecka, Lublin: Wydawnictwo KUL 2013, s. 1231-1234.

SOBÓR WATYKAŃSKI II, Dekret o działalności misyjnej Kościoła Ad gentes divinitus (Watykan, 7.12.1965).

SOBÓR WATYKAŃSKI II, Konstytucja dogmatyczna o Kościele Lumen gentium (Watykan, 21.11. 1964).

WASIUTYŃSKA K., Chrzest jako pierwotna konsekracja. U źródeł powszechnego powołania chrześcijan do świętości, „Teologia i Moralność” 10(2015), nr 1, s. 7-25.

ZADYKowicz T., Chrystopraksyzm doktryny chrzcielnej, „Teologia i Człowiek” 2016, nr 3, s. $55-76$.

\section{CHRZEST BRAMĄ CHRZEŚCIJAŃSKIEJ MORALNOŚCI. INSPIRACJE DOKUMENTU MIĘDZYNARODOWEJ KOMISJI TEOLOGICZNEJ WIARA I SAKRAMENTY}

\section{STRESZCZENIE}

Chrzest słusznie bywa nazywany bramą - bramą do zbawienia, do życia wiecznego, do Kościoła, bramą życia w Duchu, bramą nadziei, bramą do innych sakramentów. W pewnym sensie można go nazwać także bramą chrześcijańskiej moralności. Taką nazwę sugeruje pośrednio dokument Międzynarodowej Komisji Teologicznej o relacji między wiarą a sakramentami. Chrzest jest bramą, ponieważ dając udział w śmierci i zmartwychwstaniu Chrystusa, konstytuuje sam podmiot działania moralnego oraz wprowadza człowieka w aktywne uczestnictwo w życiu Kościoła i świata. To aktywne uczestnictwo realizuje się nie tylko w kulcie, ale również w życiu moralnym, które ma swoje źródło w darach sakramentalnych. Jest ono realizacją w działaniu tego, co chrzest udziela w postaci daru. Chrześcijańskie życie moralne jest zatem konsekwencją przejścia przez bramę chrztu. Na tym polega jego specyfika.

Słowa kluczowe: chrzest; sakramenty; moralność. 